\title{
Revista Colombiana de

\section{Central extracorporeal membrane oxygenation as a bridge to decision in a patient with a ventricular septal rupture complicating a myocardial infarction}

\author{
Eduardo Josué Flores-Umanzor*, Margarida Pujol-Lopéz, Victoria Martin, \\ Rut Andrea, Marta Farrero
}

Cardiology Department, Cardiovascular Institute, Hospital Clinic, University of Barcelona, Spain

Received 21 September 2017; accepted 17 December 2017

Available online 2 October 2018

\section{KEYWORDS}

Ventricular septal rupture;

Extracorporeal

membrane oxygenation circuit; Acute myocardial infarction

\section{PALABRAS CLAVE}

Ruptura del septum ventricular;

Circuito de oxigenación por membrana extracorpórea;

\begin{abstract}
In the era of primary percutaneous coronary intervention, mechanical complications after acute myocardial infarction are extremely rare, with an incidence of less than $0.5 \%$. Rupture of the ventricular septum is the least frequent occurrence. Despite early surgical repair, mortality still remains high. Patients who are at high risk of perioperative death include those with cardiogenic shock and multiorgan dysfunction. In this group, a mechanical circulatory support such as an Extracorporeal Membrane Oxygenation circuit could be used as bridge to surgical repair is feasible or heart transplantation, as it provides hemodynamic stability and the potential to correct multiorgan dysfunction. We reported a case pf ECMO device implantation as a bridge to heart transplantation in a patient with post infarction ventricular septal rupture. Unfortunately, while on the waiting list for heart transplantation with maximum priority the patient had massive diffuse alveolar hemorrhage secondary to the anticoagulation required by the equipment and died.

(c) 2018 Sociedad Colombiana de Cardiología y Cirugía Cardiovascular. Published by Elsevier España, S.L.U. This is an open access article under the CC BY-NC-ND license (http:// creativecommons.org/licenses/by-nc-nd/4.0/).
\end{abstract}

\section{Análisis de las medidas de prevención secundaria introducidas en pacientes con historia de síndrome coronario agudo}

Resumen En la era de la intervención coronaria percutánea primaria, las complicaciones mecánicas tras un infarto de miocardio agudo son extremadamente infrecuentes, con una incidencia de menos del 0,5\%. La ruptura del septum ventricular es el caso menos frecuente. A pesar de la reparación quirúrgica, la mortalidad sigue siendo elevada. Los pacientes con alto riesgo

\footnotetext{
* Corresponding author.

E-mail address: ejfu0209@gmail.com (E.J. Flores-Umanzor).
} 
Infarto de miocardio agudo de muerte perioperativa incluyen a aquellos con shock cardiógeno y síndrome de disfunción multiorgánica. En este grupo, podría utilizarse soporte circulatorio mecánico, tal como el circuito de oxigenación por membrana extracorpórea, como puente hacia la reparación quirúrgica o trasplante cardiaco, ya que aporta estabilidad dinámica y la posibilidad de corregir el síndrome de disfunción multiorgánica. Se reporta un caso de implantación de dispositivo de membrana extracorpórea, como puente al trasplante cardiaco, en un paciente con ruptura del septum ventricular tras infarto. Lamentablemente, a pesar de estar en lista de espera con prioridad máxima, sufrió una hemorragia alveolar difusa masiva, secundaria a la anticoagulación requerida por el equipo, y falleció.

(c) 2018 Sociedad Colombiana de Cardiología y Cirugía Cardiovascular. Publicado por Elsevier España, S.L.U. Este es un artículo Open Access bajo la licencia CC BY-NC-ND (http:// creativecommons.org/licenses/by-nc-nd/4.0/).

\section{Introduction}

In the era of primary percutaneous coronary intervention, mechanical complications after acute myocardial infarction (MI) such as post MI ventricular septal rupture (VSR) are pretty rare, with an incidence less than $0.5 \%$. Nevertheless, despite its declining incidence, current mortality remains extremely high- 30 -day mortality of $100 \%$ with medical treatment and $42.9 \%$, mortality with surgical treatment in current series- and appears mostly unchanged over the last few decades. ${ }^{1,2}$

In relation to surgical repair the mortality varies significantly depending on timing of surgery with a $54.1 \%$ mortality in patients who underwent surgery within 7 days of presentation compared with $18.4 \%$ mortality if repair is delayed after 7 days. ${ }^{3}$ Patients who are at high risk of perioperative death include those with cardiogenic shock and multiorgan dysfunction. In this group a mechanical circulatory support such as an extracorporeal membrane oxygenation (ECMO) circuit could be used as bridge to surgical repair is feasible or heart transplantation, as it provides hemodynamic stability and the potential to correct multiorgan dysfunction.

\section{Case presentation}

A 69-year-old man, current smoker, with previous medical history of systemic arterial hypertension was assisted in his home by the emergency medical service based on intermittent oppressive thoracic pain that had persisted for 48 hours. An electrocardiogram revealed sinus rhythm with ST segment elevation and significant $Q$ waves in anterolateral leads - general treatment measures for ST segment elevation myocardial infarction including sublingual nitroglycerin, anticoagulant with unfractioned heparin and dual antiplatelet therapy-were initiated. He was immediately transferred to the cardiac catheterization laboratory for an emergent coronary angiogram. At his arrival to the hospital, the physical examination of the patient revealed a harsh, pansystolic murmur, as well as a palpable thrill without bibasilar pulmonary crackles. Due to the previous finding a VSR complicating MI was suspected. A transthoracic echocardiogram demonstrated drop out of the apical ventricular septum and the presence of flow across the septum using color Doppler confirming the diagnosis of VSR. Severe left ventricular (LV) dysfunction and apical thinning compatible with a pseudoaneurysm were also noted. The right ventricular function was preserved. The previous findings were confirmed by a transesophageal echocardiography (fig. 1A) (Video 1-3: available in on line supplementary material). Three vessel significant coronary artery disease was observed in the coronary angiogram and an intra-aortic balloon pump was implanted to decrease LV afterload with diminishing of the shunt volume and to improve the coronary blood flow. Suddenly, the patient became hemodynamically unstable with multiorgan dysfunction requiring treatment with vasopressors and invasive mechanical ventilation. An emergent cardiothoracic consultation was performed. The Heart Team discussed the case and the surgical option was dismissed because of the large extent of the VSR, possible pseudoaneurysm and coronary artery bypass surgery. A central veno-arterial ECMO was implanted as a bridge to candidacy for heart transplantation with initial hemodynamic improvement achieved (fig. 1B). Unfortunately, while on the waiting list for heart transplantation with maximum priority the patient had massive hemoptysis secondary to diffuse alveolar hemorrhage and died.

\section{Discussion and conclusion}

The use of circulatory support in the form of an ECMO device in post infarction VSR is an adequate option to stabilize patients until surgery, when the cardiac function can be recovered with either primary repair or transplant, and medical treatment to stabilization is unsuccessful, and emergent surgery has prohibitive risk. Rozado et al. ${ }^{4}$ described a successful case of ECMO device use in post infarction VSR to stabilize patients suffering cardiogenic shock until favorable delayed surgical repair was performed. Pascual et al. ${ }^{5,6}$ reported the experience of ECMO device implantation as a bridge to successful heart transplantation in an unusual case with 2 mechanical complications of myocardial infarction-a post infarction VSR and LV pseudoaneurysm-considered surgically irreparable.

However, circulatory support in the form of an ECMO device is not free of complications, such as dreadful bleeding 


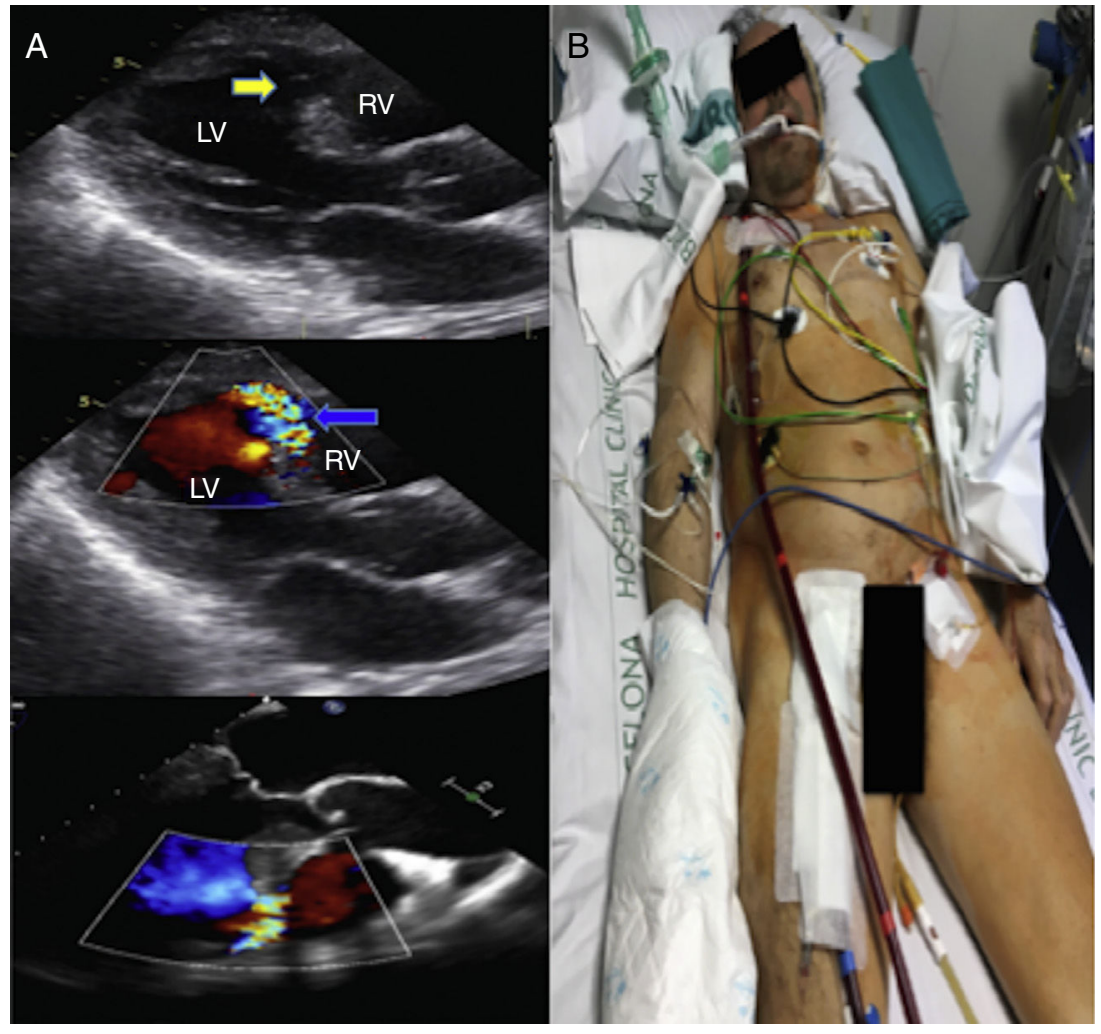

Figure 1 A transthoracic and transesophageal echocardiogram demonstrated drop out of the apical ventricular septum (Yellow arrow) and the presence of flow across the septum using color Doppler confirming the diagnosis of VSR. (Blue arrow) Severe left ventricular (LV) dysfunction and apical thinning compatible with a pseudoaneurysm were also noted. Figure 1 B A central venoarterial ECMO was implanted as a bridge to emergent heart transplantation. The venous access was located at the right atrium and the arterial access at the right femoral artery.

secondary to the anticoagulation required by the equipment like in our case or vascular and infectious complications. ${ }^{5}$

Oxigenación central por membrana extracorpórea, como puente hacia la decisión en un paciente con ruptura del septum ventricular, como complicación del infarto de miocardio

\section{Funding}

None.

\section{Conflict of interest}

None.

\section{Appendix A. Supplementary data}

Supplementary data associated with this article can be found, in the online version, at doi:10.1016/j.rccar. 2017.12.022

\section{References}

1. Jones BM, Kapadia SR, Smedira NG, et al. Ventricular septal rupture complicating acute myocardial infarction: a contemporary review. Eur Heart J. 2014;35:2060-8.

2. Flores-Umanzor, E., Caldentey, G. \& San Antonio, R. New holosystolic murmur after acute myocardial infarction. European Heart Journal: Acute Cardiovascular Care 204887261774170 (2017). doi:10.1177/2048872617741708.

3. Kutty RS, Jones N, Moorjani N. Mechanical complications of acute myocardial infarction. Cardiol Clin. 2013;31:51931.

4. Rozado J, Pascual I, Avanzas P, et al. Extracorporeal.

5. membrane oxygenation system as a bridge to reparative surgery in ventricular septal defect complicating acute inferoposterior myocardial infarction. J Thorac Dis 2017;9(9):E827-E830. doi: 10.21037/jtd.2017.08.164.

6. Pascual I, López F, Hernández-Vaquero D, et al. Circulatory support with extracorporeal membrane oxygenation system as a bridge to heart transplantation in complex postinfarction ventricular septal rupture. Rev Esp Cardiol (English Ed Elsevier. 2016;69:617-9. 